\title{
DIARRHOEA
}

\author{
A J M Watson
}

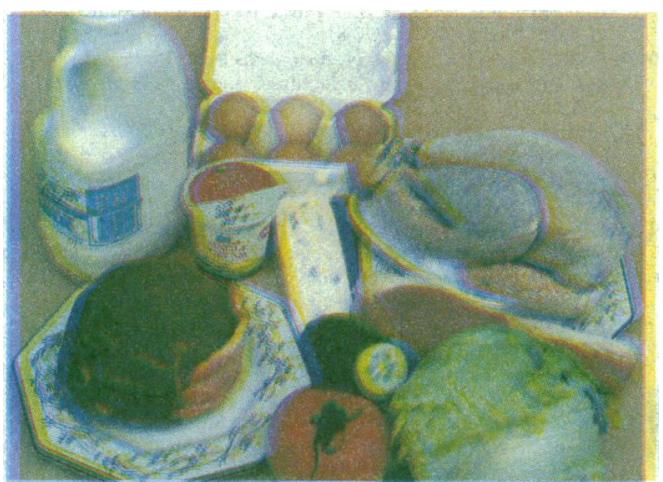

Many foods harbour diarrhoeal organisms.
Diarrhoea can be defined as the passage of more than three loose stools a day. It is due to an increase in the stool water content. In hospital diarrhoea can be more accurately defined as a stool mass of $>200 \mathrm{~g}$.

\section{History and examination}

\section{Common bacterial and protozoal causes of acute diarrhoea in the United Kingdom}

\begin{tabular}{|c|c|c|c|}
\hline Bacteria & Food source & Symptoms & $\begin{array}{l}\text { Incubation } \\
\text { period }\end{array}$ \\
\hline Salmonella spp & $\begin{array}{l}\text { Eggs, poultry, beef, } \\
\text { milk, salads }\end{array}$ & $\begin{array}{l}\text { Slimy "pea soup" stools, } \\
\text { fever }\end{array}$ & $6-24 h$ \\
\hline $\begin{array}{l}\text { Campylobacter } \\
\text { spp }\end{array}$ & Poultry, milk & $\begin{array}{l}\text { Bloody diarrhoea, } \\
\text { abdominal pain, fever, } \\
\text { generalised malaise, } \\
\text { coryza, headache }\end{array}$ & $48-72 h$ \\
\hline $\begin{array}{l}\text { Clostridium } \\
\text { perfringens }\end{array}$ & Poultry, red meat & $\begin{array}{l}\text { Watery diarrhoea, } \\
\text { abdominal pain }\end{array}$ & $8-24 h$ \\
\hline $\begin{array}{l}\text { Staphylococcus } \\
\text { aureus }\end{array}$ & $\begin{array}{l}\text { Poultry, salads, } \\
\text { milk, cream }\end{array}$ & Diarrhoea, vomiting & $2-6 h$ \\
\hline Shigella spp & $\begin{array}{l}\text { Salads, food } \\
\text { contaminated by } \\
\text { handler }\end{array}$ & $\begin{array}{l}\text { Diarrhoea initially watery } \\
\text { becoming bloody later, } \\
\text { fever }\end{array}$ & $36-48 h$ \\
\hline Bacillus cereus & $\begin{array}{l}\text { Fried and boiled } \\
\text { rice, cornflour }\end{array}$ & $\begin{array}{l}\text { Diarrhoea, abdominal } \\
\text { pain, vomiting }\end{array}$ & $1-6 h$ \\
\hline Giardia lamblia & $\begin{array}{l}\text { Water, person to } \\
\text { person contact, } \\
\text { homosexual } \\
\text { contact }\end{array}$ & Diarrhoea, steatorrhoea & 7-14 days \\
\hline
\end{tabular}

\section{History}

Diarrhoea should be distinguished from faecal incontinence with normal stool volume and frequency, the passage of blood and mucus, and the frequent passage of a small volume of stool as can occur in patients with the irritable bowel syndrome. Patients with disease of the distal colon or rectum frequently pass small quantities of dark stool, often with urgency. The presence of visible blood usually implies colonic disease. Pain is in the left lower quadrant, is relieved by defecation, and may be associated with tenesmus. In disease of the small bowel or proximal colon the stools are of large volume and watery, or, if there is steatorrhoea, pale and offensive. Pain, if present, is periumbilical or in the right lower quadrant.

If the diarrhoea is acute (lasts for less than three weeks) infective causes are likely and corroborating evidence should be sought, such as travel abroad, ingestion of raw seafood, and concomitant diarrhoea in family members and close contacts. The irritable bowel syndrome, ulcerative colitis, and Crohn's disease are the commonest causes of chronic diarrhoea in the United Kingdom. A careful history usually shows that patients with the irritable bowel syndrome suffer from frequent passage of small volumes of stool rather than "true" diarrhoea as defined above. Symptoms have often been present for many years without evidence of serious organic disease. Care should be taken in diagnosing the irritable bowel syndrome in middle aged patients as serious organic disease can be missed. If there is a change of bowel habit (constipation alternating with diarrhoea), particularly in a patient over 50 , it is mandatory to exclude colonic cancer. A drug history is also important as some frequently prescribed drugs can cause diarrhoea (for example, propranolol, methyldopa, theophylline, frusemide, and ampicillin). 


\section{Examination}

The main objective of examination of patients with acute diarrhoea is to determine the severity of dehydration and electrolyte depletion. Fever suggests infection with Salmonella, Shigella, or Campylobacter species. A rectal examination and sigmoidoscopy should be performed, both to assess the degree of rectal inflammation if present and to obtain faeces for analysis.

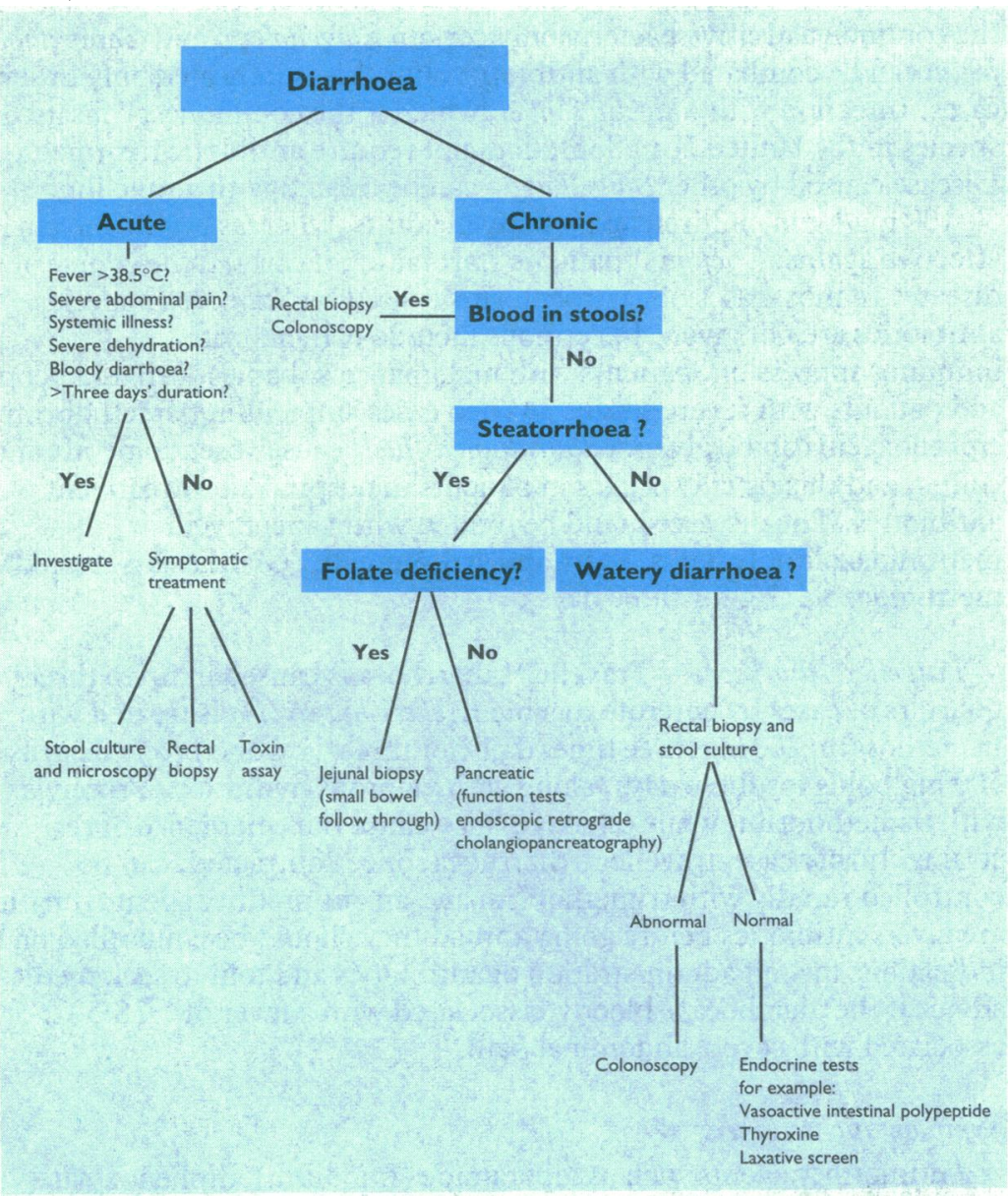

Investigation of diarrhoea.

\section{Investigation}

In patients with acute diarrhoea investigations should be concentrated initially on identifying possible infective agents. In patients with chronic diarrhoea sigmoidoscopy and rectal biopsy are mandatory to assess mucosal inflammation and to find out whether melanosis coli is present, which might indicate laxative abuse.

\section{Useful simple tests}

Stool volume-Measurement of stool volume is an essential part of the assessment of diarrhoea and monitoring its treatment in hospital. The mass of stools in grammes is equivalent to their volume in millilitres. If the stools cannot be weighed immediately they can be frozen.

Stool electrolytes - In patients with large volume diarrhoea measurement of stool electrolyte concentrations can be helpful. The stool osmolality can be estimated as $290 \mathrm{mmol} / \mathrm{kg}$ as the colon has no capacity to concentrate internal contents. If the stool osmotic gap (stool osmolality minus twice the sodium concentration plus the potassium concentration) is greater than $175 \mathrm{mmol} / \mathrm{kg}$ then the diarrhoea is likely to be due to the presence of a non-absorbed solute. If the osmotic gap is less than $50 \mathrm{mmol} / \mathrm{kg}$ then the diarrhoea is likely to be a result of secretion. Intermediate values are the result of a mixture of pathophysiological causes.

Stool analysis by alkalinisation-An important, though uncommon, cause of chronic high volume, watery diarrhoea is misuse of purgatives. Ingestion of phenolphthalein can be identified easily as the stool will turn red on addition of an alkali. Other laxatives can be identified by more detailed chemical analysis.

\section{Treatment}

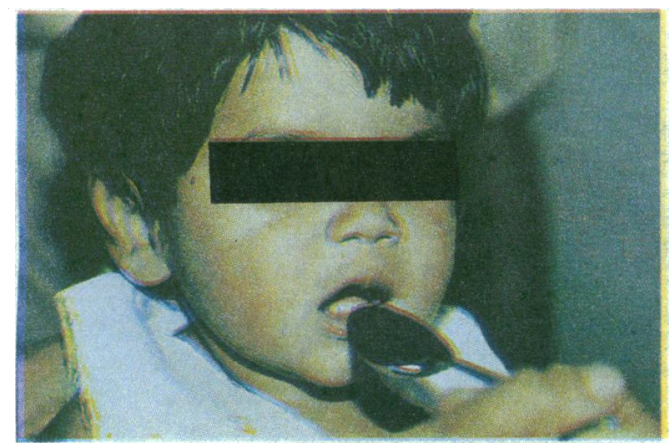

Child being treated with oral rehydration solution.
The treatment of diarrhoea will depend on the cause. Some general principles are discussed below.

\section{Rehydration}

In the United Kingdom there is still an appreciable mortality from diarrhoeal disease in infants and elderly people because of inadequate rehydration. A postural drop in diastolic blood pressure of $>20 \mathrm{~mm} \mathrm{Hg}$ or a rise in pulse of $>20$ beats $/$ minute or fever of $>38.5^{\circ} \mathrm{C}$ together with severe abdominal pain are signs of severe disease. In such cases treatment with intravenous fluids in hospital is mandatory. In milder cases rehydration should be with oral rehydration fluids. Usually this can be achieved adequately at home. 


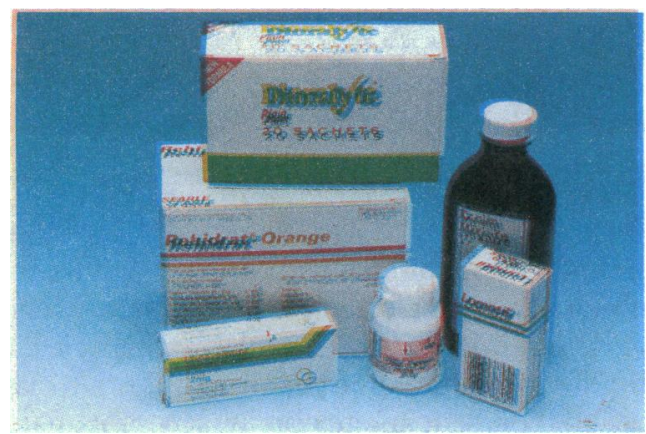

Some popular antidiarrhoeal drugs.

\section{Indications for antibiotic treatment}

- Severe cases of infection with Shigella spp and Campylobacter jejuni

For Shigella spp other than $S$ sonnei give ampicillin $50-100 \mathrm{mg} / \mathrm{kg}$ in children, $2 \mathrm{~g}$ daily in adults

For $C$ jejuni give erythromycin in severe cases

- Immunosuppressed patients, babies, and very old people infected with Salmonella spp-give ampicillin, trimethoprim, or ciprofloxacin

- Severe cases of infection with Clostridium difficile-give vanamycin or metronidazole

- Giardiasis-give metronidazole $2 \mathrm{~g}$ for three days
The optimal formulation of oral rehydration fluids is still debated but a sodium ion concentration of $50-70 \mathrm{mmol} / 1$ (Rehidrat, Electrolade) is probably best for United Kingdom practice. The recommended sodium ion concentration in the British National Formulary is probably too low (35-60 $\mathrm{mmol} / \mathrm{l}$ ) whereas that recommended by the World Health Organisation is too high $(90 \mathrm{mmol} / \mathrm{l})$ and more appropriate for Third World practice where sodium ion depletion is common. With young children sips of the fluid $(5-10 \mathrm{ml})$ should be given every 10 minutes. Research has shown that despite vomiting adequate rehydration can be achieved if it is administered this way.

\section{Antibiotic treatment}

Antibiotics are not usually indicated for diarrhoea. In the United Kingdom most acute infective diarrhoeal illnesses are caused by viruses. Of the common causative bacteria only certain Shigella spp and Campylobacter jejuni can be combated with antibiotics, but this is indicated only in severe cases. Infection with Shigella sonnei, which is the commonest causative species in the United Kingdom, does not require antibiotic treatment. Disease caused by other Shigella spp can be treated with ampicillin, $50-100 \mathrm{mg} / \mathrm{kg}$ in children or $2 \mathrm{~g}$ daily in adults, whereas erythromycin is effective against $C$ jejuni if patients start taking it early in the course of the disease. In most cases of gastroenteritis caused by Salmonella species antibiotics are not given. Exceptions include patients with immunosuppression, patients with malignancies, babies, very old people, and patients with severe sepsis. In such cases ampicillin, trimethoprim, or ciprofloxacin can be given. Clostridium difficile causes pseudomembranous colitis, and this usually occurs in patients in hospital after treatment with antibiotics. The disease should be treated with vancomycin or metronidazole only if it is severe and symptomatic. Giardiasis is treated with metronidazole ( $2 \mathrm{~g}$ for three days).

Traveller's diarrhoea-Traveller's diarrhoea is caused in up to three quarters of cases by enterotoxogenic Escherichia coli. It is treated with trimethoprim $200 \mathrm{mg}$ three times daily for three days or ciprofloxacin as a $500 \mathrm{mg}$ bolus for three days, along with vigorous hydration. Prophylaxis with trimethoprim, while effective, may cause the emergence of resistant strains. In any case, traveller's diarrhoea, once contracted, can be controlled rapidly with trimethoprim and an antimotility agent. If patients are given antibiotics before going abroad they should be counselled on the indications for self administration of antibiotics and told to seek medical advice if the diarrhoea is bloody, associated with a fever of $>38 \cdot 5^{\circ} \mathrm{C}$, or associated with severe abdominal pain.

\section{Symptomatic treatment}

Antimotility agents such as loperamide (Imodium), diphenoxylate (Lomotil), and codeine are effective for treating symptoms. They are contraindicated in acute infective diarrhoea with bloody stools as they will slow the clearance of infective agents. They can, however, be helpful in ulcerative colitis and Crohn's disease, though they should be used with caution in severe exacerbations as toxic dilatation can be induced.

The photographs were produced by the department of medical illustration, Salford Health Authority.

Dr A J M Watson is tutor in medicine, Hope Hospital, Salford.

The ABC of Colorectal Diseases has been edited by Mr D J Jones, lecturer and honorary senior registrar, and Professor M H Irving, department of surgery, Hope Hospital, Salford. 